\title{
Clinical Significance and Prevalence of Frailty Syndrome in Type 2 Diabetes Patients
}

\author{
Tip 2 Diyabetli Hastalarda Kırılganlık Sendromunun Sıklı̆̆ı ve Klinik Önemi
}

Betul Alaca, Mehmet Zahid Kocak, Mujgan Gurler

Abant Izzet Baysal University Hospital, Department of Internal Medicine, Bolu, Turkey

Correspondence:

Mehmet Zahid KOÇAK

Abant Izzet Baysal University

Hospital, Department of Internal

Medicine, Bolu, Turkey

e-mail: mehmetzahidkocak@hotmail. com

\section{Abstract}

In this study, we aimed to evaluate the prevalence of frailty in type 2 diabetes mellitus (T2DM) and to investigate the relations between frailty and T2DM. One hundred twenty-five patients with T2DM diagnosis were included in the study. According to the Fried's frailty scale, the patients were grouped as frail, pre-frail and non-frail, and their prevalence was determined. Demographic data, anthropometric measurements and laboratory data were compared between the groups. The harmonic mean of the group sizes is used as the group size was not equal. The frail patients' number was 11 (8\%), the pre-frail patients' number was 83 (66\%), and the non-frail patients' number was $31(26 \%)$ in the study. The median age of the frail group was $65(51-88)$ years, the pre-frail group was $61(50-78)$ years, and the non-frail group was $61(50-80)$ years $(\mathrm{p}=0.15)$. There was no statistically significant difference between in body mass index, diabetes duration, systolic and diastolic blood pressure, and co-morbidity between the groups ( $\mathrm{p}>$ 0.05 for all). Fasting plasma glucose, $\mathrm{HbAlc}$, triglyceride, hand grip strength and gait speed were statistically significantly different between groups ( $\mathrm{p}<0.05$ for all). Impaired glucose regulation, low gait speed and hand grip strength test were detected in patients with pre-frail T2DM. Patients with T2DM are candidates for frailty at an earlier age.

Keywords: frailty, gait speed, handgrip strength, type 2 diabetes mellitus

\section{Özet}

Bu çalışmada tip 2 diyabetes mellitusta (T2DM) kırılganlık sendromunun sıklığını ve kırılganlık ile T2DM arasındaki ilișkiyi değerlendirmeyi amaçladık. Çalışmaya T2DM tanılı yüz yirmi beș hasta dahil edildi. Fried'in kırılganlık ölçeğine göre hastalar kırılgan, pre-kırılgan ve kırılgan olmayan olarak gruplandırıldı ve sıklıkları belirlendi. Gruplar arasında demografik veriler, antropometrik ölçümler ve laboratuvar verileri karşılaştırıldı. Grup büyüklüğü eşit olmadığ için grup büyüklüklerinin harmonik ortalaması kullanılmıştır. Çalışmada kırılgan hasta sayısı 11 (\%8), pre-kırılgan hasta sayısı 83 (\%66), kırılgan olmayan hasta sayısı 31 (\%26) idi. Kırılgan grubun ortanca yaşı 65 (51-88) yıl, pre-kırılgan grubun 61 (50-78) yıl ve kırılgan olmayan grup 61 (50-80) yıl ( $\mathrm{p}=0.15)$ idi. Gruplar arasında vücut kitle indeksi, diyabet süresi, sistolik ve diyastolik kan basıncı ve komorbidite açısından istatistiksel olarak anlamlı fark yoktu (hepsi için p>0.05). Açlık plazma glukozu, HbA1c, trigliserit, el kavrama gücü ve yürüme hızı gruplar arasında istatistiksel olarak farklı bulundu (tümü için p<0.05). Pre-frail T2DM’li hastalarda bozulmuş glukoz regülasyonu, düşük yürüme hızı ve el kavrama gücü saptandı. T2DM’li hastalar daha erken yaşta kırılganlık için adaydır.

Anahtar Kelimeler: kırılganlık, yürüme hızı, el kavrama gücü, tip 2 diabetes mellitus 


\section{Introduction}

Type 2 diabetes mellitus (T2DM) is an important public health problem, as its prevalence is globally increasing (1). The development of diabetic complications (retinopathy, nephropathy, neuropathy) increases dramatically after 10 years of the disease (2). These complications are associated with disability, functional decline, and loss of quality of life (QoL) (3). Among older diabetic adults, frailty syndrome is arising as a major complication, in addition to the macro- and microvascular issues leading to considerable disability. Frailty is a state of reduced reserve and resistance to stressors from cumulative decline across several physiologic systems, coinciding with aging (4); this also leads to vulnerability to adverse outcomes, such as hospital admissions, falls, additional disabilities, and death (4-6). In contrast to disability, frailty is a dynamic process, but is potentially reversible (7). Diabetes pathophysiology is tightly related to frailty: long-term duration increases the loss of skeletal muscle function and mass, leading to decreased gait speed and mobility (8). Autonomic neuropathy may cause orthostatic hypotension, syncope, bladder dysfunction, and the absence of typical hypoglycemic symptoms such as sweating, tachycardia, and tremors; it is also related to adverse events, such as urinary incontinence, malnutrition, and falls, which finally lead to frailty (9).

Several studies shows that T2DM patients are more likely to become frail than non-diabetic older adults (10-12). The prevalence of frailty in adults ( $\geq 65$ years) is 3 - to 5-fold higher with T2DM than in the general population $(13,14)$. The National Health and Nutrition Examination Survey (NHANES) and The Cardiovascular Heart Study (CHS) data indicate that frailty and pre-frailty are present in $25 \%$ and $18.2 \%$ of T2DM, respectively (15, 16). Another study shows that the highest prevalence of frailty with T2DM (19.3\%) compares to $11.4 \%$ and $11.9 \%$ in prediabetic and nondiabetic individuals, respectively (17).

The significance of frailty has been steadily recognized in guidelines for diabetes management (18); its prevalence varies in
T2DM, due to significant heterogeneity between population characteristics and frailty definitions. There are very few articles that correlate frailty syndrome and clinical outcomes in elderly adults with T2DM in our population. In this study, we aimed to assess the prevalence of frailty and its clinical significance in diabetic patients.

\section{Materials and methods}

This cross-sectional study was conducted between Aug 2019 and Feb 2020 in Abant Izzet Baysal University Medical Faculty Hospital department of Internal Medicine in Bolu, Turkey. Ethics committee approval was obtained for our study (approval number: 2019/02). It was planned to include diabetic patients 50 years and older in the study. 300 patients were evaluated for the study. 40 (15\%) patients refused to participate in the study. $20(7.5 \%)$ patients with active infection, $14(5.2 \%)$ patients with previous cerebrovascular events, $18(6.7 \%)$ patients with acute coronary syndrome in the last 3 months, $45(16.9 \%)$ patients with severe gonatrosis and $3(\%)$ with malignancy 1.1) patients were excluded from the study. 125 patients were included in the study. The number of patients required was calculated as at least 110 using the alpha value of 0.08 according to the $\mathrm{t}$ test for $90 \%$ power using the G-power program. Age, gender, systolic blood pressure (SBP), diastolic blood pressure (DBP) chronic comorbidity, medication (oral antidiabetic drugs, insulin therapy), diabetic microvascular complications, and anthropometric measurements (height, waist circumference, hip circumference, weight, calf circumference, mid arm circumference, triceps, and biceps skin thickness) and laboratory data were recorded. By measuring the height and weight of the patients, body mass index (BMI) was calculated with the formula weight $(\mathrm{kg}) /[$ height $(\mathrm{m})] 2$.

Hand grip strength test was performed with CARMY brand Electronic hand dynamometer. Skin fold thicknesses were measured with Body Fat Caliper. Frailty was evaluated with Fried's frailty scale (16), which 
has high validity and reliability in many patient populations. Five components are considered in the Fried's Frailty phenotype (16). The five parameters to be examined in this scale are as follows: 1 . Unintended weight loss (involuntary loss of $4.5 \mathrm{~kg}$ or more than $5 \%$ of total body weight in the last 1 year). 2 . Weakness (Hand grip strength measurement with hand dynamometer: evaluated according to BMI and gender). 3. Self-reported exhaustion: Patients are asked questions 7 and 20 in the Center for Epidemiologic Studies Depression (CES-D) scale to determine their fatigue. These questions: 'I felt that everything I did was an effort' and 'I could not get going'. 4. Slowness: Walking time $4.57 \mathrm{~m}$ (adjusted for sex and height) in the lowest quintile. 5. Low physical activity: (Energy expenditure: Men: $<383 \mathrm{kcal} /$ week, Women: $<270 \mathrm{kcal} /$ week). The patient was classified as "Not-frail" no criteria are met, "Pre-frail" one or two criteria are met, and "Frail" at least three criteria are met (16).

\section{Statistical analysis}

Descriptive statistics are given as mean \pm standard deviation, median (min-max) for numerical variables, and as number and percentage values for categorical variables. In study groups, distribution of study variables was evaluated with the Kolmogorov-Smirnov test. One-way analysis of variance (ANOVA) was used in comparison of the variables. Tukey HSD post hoc analysis was performed for data that were normally distributed, and Games-Howell analysis was performed for data that were not normally distributed. The harmonic mean of the group sizes is used as the group size was not equal. Chi-square test was used to compare categorical variables between groups. Correlation analysis was conducted by Pearson correlation test. P $<0.05$ was determined as the statistical significance level. Analyzes were made using SPSS v.21.

\section{Results}

There were 125 subjects in the study. Out of 125 subjects, only $11(8 \%)$ were frail. Most patients were pre-frail $(\mathrm{n}=83,66 \%)$ and $31(26 \%)$ were not-frail $(\mathrm{p}<0.001)$. Mean age of our population was $61.9 \pm 7.6$ years. Most patients were female $(n=79,63 \%)$. Demographic and clinical characteristics of the study population are presented in table 1 . Nine $(11.4 \%)$ of 11 in frail group were female and $2(4.3 \%)$ were male, $52(65.8 \%)$ of 83 in pre-frail group were female, $31(67.4 \%)$ were male, $18(22.8 \%)$ of 32 in not-frail group were female, $13(28.3 \%)$ were male. Gender was not statistically different between groups $(\mathrm{p}=0.36)$. In study group, female BMI $(33.3$ [20.5-44.7]) was significantly higher than male BMI (29.5 [21.2-47.5]) (p <0.001). Female handgrip strength was 22.6 (10.349.6) $\mathrm{kg}$, was $36.2(14.3-78.8) \mathrm{kg}$ in male $(p<0.001)$. SBP $(p=0.8)$, DBP $(p=0.9)$, BMI $(p=0.32)$, retinopathy $(p=0.36)$, neuropathy $(\mathrm{p}=0.7)$, nephropathy $(\mathrm{p}=0.15)$, medication $(\mathrm{p}>0.05$ for all) and chronic comorbidity ( $>0.05$ for all) number of the frail, pre-frail and not-frail groups were not statistically different. There was no major influence on the limb functions in the visual performance of the patients with microvascular complications. The general characteristics of the study population are summarized in table 2 .

Table 1. Demographic and Clinical Characteristics of the Study population

\begin{tabular}{llc}
\hline \multicolumn{2}{c}{ Study population [n, \%, Mean \pm St.D., Median (mi-max)] } \\
\hline Gender (n) & $\begin{array}{l}\text { Female (\%) } \\
\text { Male (\%) }\end{array}$ & $79(63)$ \\
Body Mass Index & Female & $46(37)$ \\
$\mathbf{( k g / \mathbf { m } ^ { 2 } )}$ & Male & $33.3(20.5-44.7)$ \\
Hand Muscle & Female & $29.5(21.2-47.5)$ \\
strength (kg) & Male & $22.6(10.3-49.6)$ \\
& & $36.2(14.3-78.8)$ \\
Microvascular & Retinopathy (\%) & \\
complication (n) & Neuropathy (\%) & $23(18)$ \\
& Nephropathy (\%) & $85(68)$ \\
& & $49(39)$ \\
\hline
\end{tabular}




\begin{tabular}{llc}
\hline Frailty Status (n) & $\begin{array}{l}\text { Frail (\%) } \\
\text { Pre-frail (\%) } \\
\text { Not-frail (\%) }\end{array}$ & $11(8)$ \\
& $\begin{array}{l}\text { Hypertension } \\
\text { Hyperlipidemia } \\
\text { Coronary artery disease }\end{array}$ & $31(26)$ \\
\hline $\begin{array}{l}\text { Chronic } \\
\text { comorbidity (n) }\end{array}$ & 91 \\
& 25 \\
\hline Age (year) & 42 \\
\hline Diabetes duration (year) & $61.9 \pm 7.6$ \\
\hline Systolic Blood pressure (mm/Hg) & $11.6 \pm 6.9$ \\
\hline Diastolic blood pressure (mm/Hg) & $140.6 \pm 19.5$ \\
\hline Fasting plasma glucose (mg / dl) & $82.7 \pm 10.3$ \\
\hline HbA1c (\%) & $192(84-536) 6$ \\
\hline LDL-cholesterol (mg / dl) & $8.9(5.9-14.2)$ \\
\hline HDL-cholesterol (mg / dl) & $110.2(29.9-229.6)$ \\
\hline Triglyceride (mg / dl) & $44.2(18.9-76.9)$ \\
\hline Total cholesterol (mg / dl) & $142(44-429)$ \\
\hline Oral antidiabetic drug monotherapy & $185(93-324)$ \\
\hline Combined oral antidiabetic drug & $47(36.7)$ \\
\hline Oral antidiabetic drug + Insulin & $61(48.8)$ \\
\hline Insulin monotherapy & $54(43.2)$ \\
\hline Intensive insulin therapy & $12(9.6)$ \\
\hline
\end{tabular}

Table 2. Distribution of Demographic and Clinical Characteristics of the Study Groups

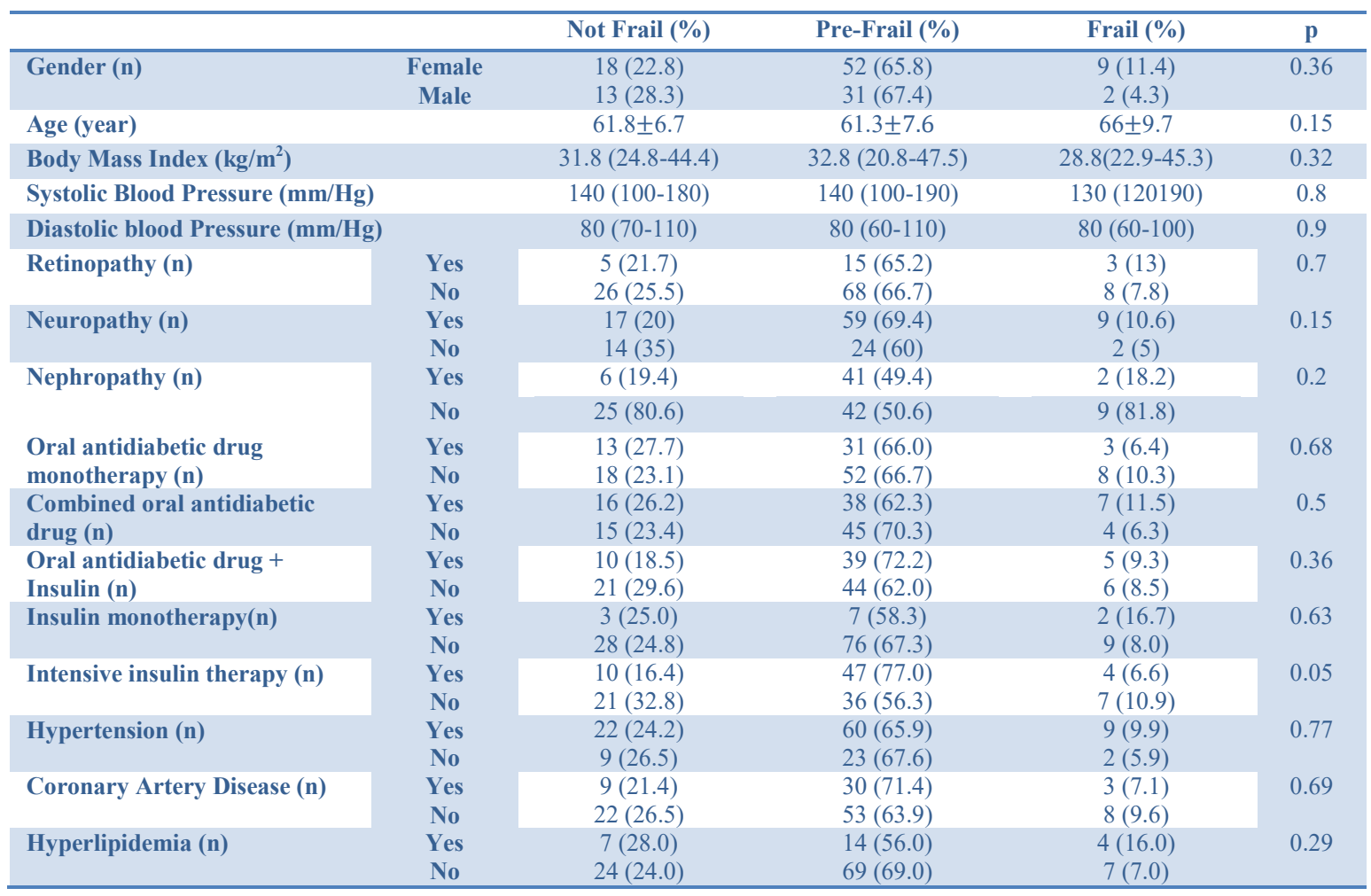


Mean fasting plasma glucose (FPG) levels of frail group, pre-frail group and not-frail group were $280.18 \pm 26 \mathrm{mg} / \mathrm{dl}, 218.12 \pm 10.5 \mathrm{mg} /$ $\mathrm{dl}$, and $156.71 \pm 10.2 \mathrm{mg} / \mathrm{dl}$, respectively (p $<0.001$ ). In Post Hoc analysis, FPG level of not-frail group was significantly lower than pre-frail $(\mathrm{p}<0.001)$ and frail group $(\mathrm{p}=0.002)$, however there was not significant difference between pre-frail and frail group in Post Hoc analysis $(p=0.1)$. Median HbAlc levels of not-frail, pre-frail and frail group were $7.6 \%$ (5.9 - 11.9), 9.5\% (6.3 - 14.2) and $11.7 \%$ (8.4 - 14.2), respectively ( $\mathrm{p}<0.001)$. In subgroup analysis, median HbAlc of frail group was significantly higher than both pre-frail ( $\mathrm{p}=$ $0.04)$ and not-frail group $(p<0.001)$. Median $\mathrm{HbA1c}$ of pre-frail group was significantly higher than not-frail group ( $p<0.001)$. Triglyceride levels were statistically different between groups $(p=0.021)$, however, in Post Hoc analysis, there was only a significant difference between pre-frail and frail group ( $p$
$=0.03)$. Hand grip strength was statistically significant between the groups in female ( $p=$ 0.022) (Table 3-4). Hand grip strength numerically lower in frail group than pre-frail and not-frail group in female. However, in subgroup analysis, there was not statistically different between study groups. ( $p>0.05$ for all) (Table 4). In male patients, hand grip strength was not statistically different between pre-frail, frail, and not-frail group $(\mathrm{p}=0.39)$ (Table 3). Walking time was $9.25(7-14) \mathrm{sec}$ in the not-frail group, $10.1(6.6-19) \mathrm{sec}$ in the pre-frail group and $12(7.5-20)$ seconds in the frail group in female $(\mathrm{p}=0.002)$. Walking time numerically higher in frail group than pre-frail and not-frail group in female. But in subgroup analysis, there was not significant difference between groups ( $\mathrm{p}>$ 0.05 ). (Table 3 ). In male patients, walking time was not statistically different between pre-frail, frail, and not-frail group $(\mathrm{p}=0.23)$ (Table 3).

Table 3. Laboratory and anthropometric measurements between study groups

\begin{tabular}{|c|c|c|c|c|}
\hline & Not-frail & Pre-Frail & Frail & \\
\hline & \multicolumn{3}{|c|}{ Mean \pm St.D. } & $\mathbf{p}$ \\
\hline Leukocyte (K/ u) & $7.68 \pm 2.11$ & $8.23 \pm 2.14$ & $6.84 \pm 1.35$ & 0.07 \\
\hline Glomerular filtration rate $\mathrm{ml} / \mathrm{min} / \mathbf{1 . 7 3}$ & $82.84 \pm 13.13$ & $82.13 \pm 12.95$ & $79.33 \pm 11.10$ & 0.7 \\
\hline Uric Acid (mg / dl) & $4.66 \pm 1.20$ & $4.87 \pm 1.34$ & $4.61 \pm 1.54$ & 0.25 \\
\hline Fasting Plasma Glucose (mg / dl) & $156.71 \pm 10.2$ & $218.12 \pm 10.5$ & $280.18 \pm 26$ & $<0.001$ \\
\hline LDL- Cholesterol (mg/dl) & $115.54 \pm 27.54$ & $115.35 \pm 36.31$ & $94.88 \pm 37.01$ & 0.18 \\
\hline \multirow[t]{2}{*}{ Total Cholesterol (mg / dl) } & $188.71 \pm 31.13$ & $192.2 \pm 48.11$ & $165.18 \pm 44.29$ & 0.16 \\
\hline & \multicolumn{3}{|c|}{ Median (Min-Max) } & $\mathrm{p}$ \\
\hline Hemoglobin (g / dl) & $13.5(8.7-16.3)$ & $13.5(8.8-17.9)$ & $13.4(11.3-14.5)$ & 0.9 \\
\hline Creatinine (mg / dl) & $0.82(0.6-1.2)$ & $0.82(0.2-1.2)$ & $0.78(0.5-1.1)$ & 0.57 \\
\hline Urea (mg / dl) & $30(15-43)$ & $30(17-83)$ & $34(24-54)$ & 0.29 \\
\hline HbA1c \% & $7.6(5.9-11.9)$ & $9.5(6.3-14.2)$ & $11.7(8.4-14.2)$ & $<0.001$ \\
\hline HDL- Cholesterol (mg/dl) & $44.2(27.5-69.3)$ & $44.2(18.9-76.9)$ & $47.2(28.4-73.8)$ & 0.81 \\
\hline Triglyceride (mg / dl) & $127(44-300)$ & $154.5(58-427)$ & $104(64-280)$ & 0.021 \\
\hline Albumin (g/ dl) & $4.3(3.4-4.8)$ & $4.4(2.8-5)$ & $4.2(3.5-4.3)$ & 0.06 \\
\hline Total Protein (g / dl) & $7.2(5.7-8.1)$ & $7.3(5.4-8.6)$ & $7.3(6.7-8.2)$ & 0.65 \\
\hline $\operatorname{AST}(\mathbf{u} / \mathbf{L})$ & $19(8-89)$ & $17(8-72)$ & $20(10-23)$ & 0.93 \\
\hline $\operatorname{ALT}(\mathbf{u} / \mathbf{L})$ & $19(7-64)$ & $17(7-53)$ & $16(11-23)$ & 0.53 \\
\hline Proteinuria (mg / dl) & $11.12(2.56-390.55)$ & $\begin{array}{c}29.32(1.23- \\
1424.5)\end{array}$ & $\begin{array}{c}12.08(2.34- \\
225.13)\end{array}$ & 0.23 \\
\hline Middle arm circumference $(\mathrm{cm})$ & $31(24-41)$ & $31(22-40)$ & $30(21-36)$ & 0.66 \\
\hline Calf circumference $(\mathrm{cm})$ & $36(10-47)$ & $36(8-55)$ & $35(14-50)$ & 0.77 \\
\hline Biceps skinfold thickness (mm) & $18(12-41)$ & $18(6-45)$ & $18(12-40)$ & 0.28 \\
\hline Triceps skinfold thickness (mm) & $18(8-28)$ & $16(6-32)$ & $16(10-24)$ & 0.36 \\
\hline Hand Muscle strength Female & $29(12-49.6)$ & $21.9(10.3-45.2)$ & $21.8(10.6-45.9)$ & 0.022 \\
\hline (kg) & $38.6(30.8-68.1)$ & $33.6(14.3-78.7)$ & $46.85(20.6-52.5)$ & 0.39 \\
\hline Walking time (sec) & $9.25(7-14)$ & $10.1(6.6-19)$ & $12(7.5-20)$ & 0.002 \\
\hline Male & $9(7.9-11)$ & $9.7(7-20)$ & $10.65(8.3-13)$ & 0.23 \\
\hline
\end{tabular}


Table 4. Subgroup analysis of dependent variables between patient groups

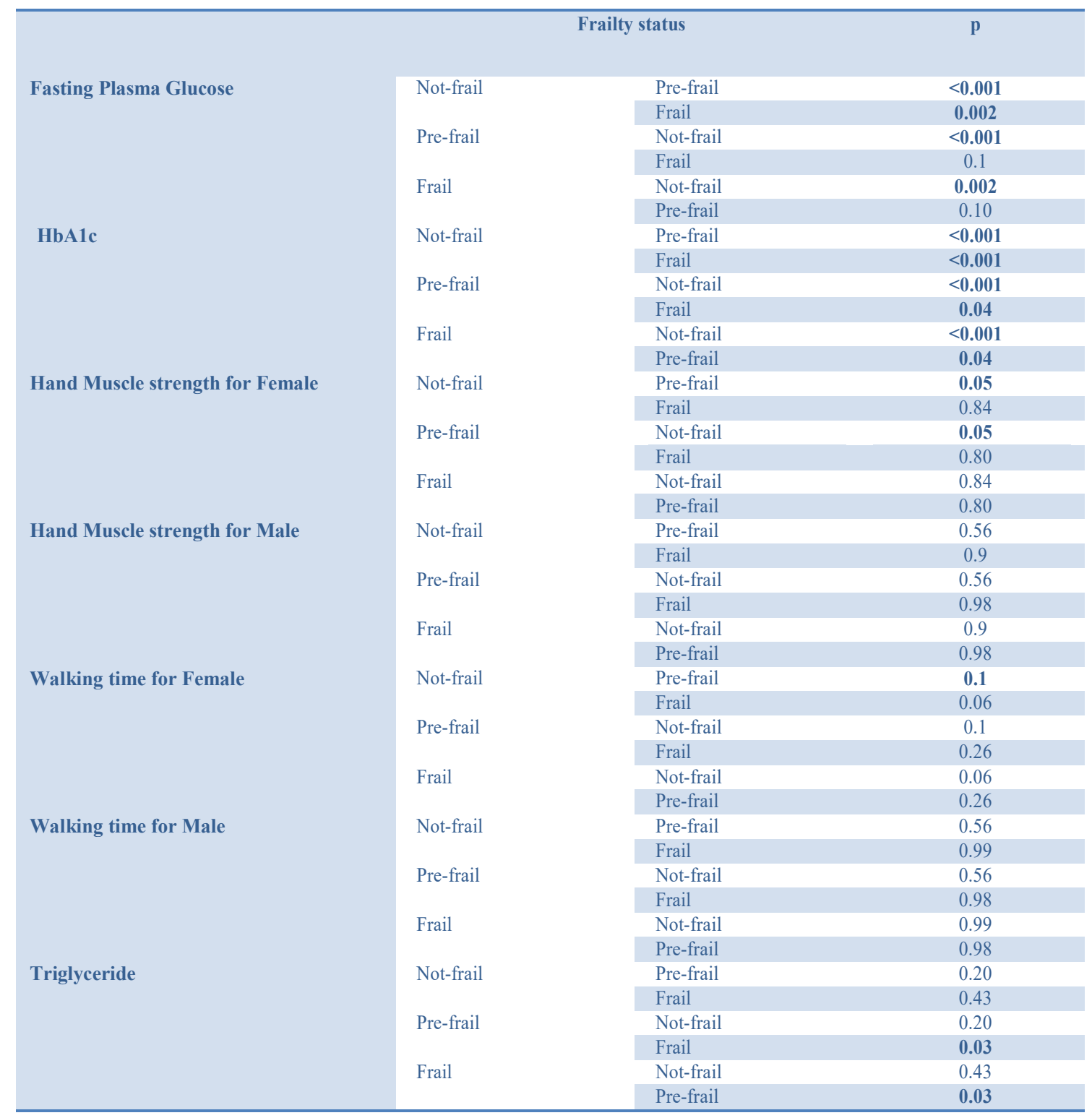

\section{Discussion}

In present study, we estimated the prevalence of not-frail, pre-frail, and frail in T2DM patients, based on a widely used Fried's frailty phenotype. Pre-frail group was higher in patients with T2DM than not-frail and frail group. FPG and HbAlc levels were higher in frail group than in the pre-frail and not-frail groups, and higher than in pre-frail group than not-frail group. Another substantial outcome of the study was reduced hand grip strength in frail female subjects compared to pre-frail and not-frail female subjects. Again, walking time was found to be higher in the female frail group compared to the other groups.

Frailty is heterogeneous concept, and there is no standard description or measure (19). Multiple definitions of frailty exist. Some are based on physical assessments such as grip strength and walking pace or self-reported measures. Some are based on medical records. The distribution of prevalence is wide due to differences in definition and determination of frailty. In some studies frailty prevalence was $4-16 \%$ in patients over 65 years, and pre-frail prevalence was between $28-44 \%$ (20). 
Another study with diabetic patients found a prevalence of frailty between $32 \%$ and $48 \%$ (10). In our study, frail group prevalence was $8 \%$ of the study population. Pre-frail group prevalence was $66 \%$. Our study showed that pre-frail prevalence was higher in patients with T2DM than other studies. In our study group, the prevalence of not-frail group was lower than other studies. The reason for the low prevalence of not-frail group may be due to the regional and patient characteristics and frailty screening tool.

Especially, higher $\mathrm{HbA1c}$ goals are recommended in the context of frailty, in part due to the increased risks related with hypoglycemia (18). Contrarily, poor glycemic control and related vascular complications may cause or accelerate the progression of frailty (21). In a recent study, a 'U-shaped' relation between frailty and plasma glucose as evaluated by frailty scale, glucose levels $<8.8$ $\mathrm{mmol} / \mathrm{L}$ and $>10 \mathrm{mmol} / \mathrm{L}$, was associated with an increased risk of frailty $(22,23)$. The significance of frailty is identified in diabetes guidelines (18). Especially, broader HbAlc goals are recommended, and the risks of hypoglycemia are emphasized (18). In our study, HbA1c and FPG levels were higher in frail group than pre-frail and not-frail group and were higher in pre-frail group than notfrail group. Mean age of our study group is $61.9 \pm 7.3$ year. The target $\mathrm{HbA} 1 \mathrm{c}$ level in this age group is $<6.5 \%$. Therefore, the high FPG and $\mathrm{HbAlc}$ levels in the frail and pre-frail

\section{REFERENCES}

1. Shaw JE, Sicree RA, Zimmet PZ. Global estimates of the prevalence of diabetes for 2010 and 2030 . Diabet Res Clin Pract. 2010;87:4-14.

2. Fowler MJ. Microvascular and macrovascular complications of diabetes. Clin Diabet. 2008;26:77-82.

3. Wong E, Backholer K, Gearon E et al. Diabetes and risk of physical disability in adults: a systematic review and meta-analysis. Lancet Diabetes Endocrinol. 2013;1:106-14.

4. Clegg A, Young J, Iliffe S et al. Frailty in elderly people. Lancet. 2013;381:752-62.

5. Morley J, Kim M, Haren M et al. Frailty and the aging male. Aging Male. 2005;8:135-40.

6. Kojima G, Iliffe S, Walters K. Frailty index as a predictor of mortality: a systematic review and meta-analysis. Age Ageing. 2018;47:193-200. groups were thought to be a result of frailty status. T2DM is associated with loss of skeletal muscle mass and function $(24,25)$. Hand grip strength screening test has been reported to be an effective protective factor to determine muscle weakness and decline muscle function (25-27). Studies show that hand grip strength correlates with T2DM regulation $(25,28)$. In our study, the hand grip strength of the pre-frail patient group was significantly lower than the not-frail group in female, not significantly in male.

There are limitations to our study. 1. The number of patients in the study group was relatively few. 2 . The number of patients was not homogeneous in the frail, pre-frail, and not-frail groups (The harmonic mean of the group sizes is used). 3. The effect of our patients' comorbidities on frailty is not fully known, even if comorbidities are equally distributed in the entire patient group.

\section{Conclusions}

In this study, frail patient prevalence in T2DM was consistent with the literature. In addition to the literature another important outcome, pre-frail patient prevalence was found more than frail and not-frail group. Glucose regulations of frail and pre-frail diabetic patients should be approached exhaustively by clinicians. Considering that pre-frail patients may be more common in patients with T2DM, treatment goals should be evaluated accordingly.

7. Apóstolo J, Cooke R, Bobrowicz-Campos E et al. Effectiveness of interventions to prevent prefrailty and frailty progression in older adults: a systematic review. JBI Database System Rev Implement Rep. 2018;16:140.

8. Kalyani RR, Corriere M, Ferrucci L. Age-related and disease-related muscle loss: the effect of diabetes, obesity, and other diseases. Lancet Diabetes Endocrinol. 2014;2:819-29.

9. Yoon SJ, Kim KI. Frailty and Disability in Diabetes. Ann Geriatr Med Res. 2019;23:165-9.

10. Ottenbacher KJ, Graham JE, Al Snih $\mathrm{S}$ et al. Mexican Americans and frailty: findings from the Hispanic established populations epidemiologic studies of the elderly. Am $J$ Pub Healt. 2009;99:673-9. 
11. Cacciatore F, Testa G, Galizia G et al. Clinical frailty and long-term mortality in elderly subjects with diabetes. Acta Diabetol. 2013;50:251-60.

12. Hubbard R, Andrew $\mathrm{M}$, Fallah $\mathrm{N}$ et al. Comparison of the prognostic importance of diagnosed diabetes, co-morbidity and frailty in older people. Diabet Med. 2010;27:603-6.

13. Saum K-U, Dieffenbach AK, Müller $H$ et al. Frailty prevalence and 10-year survival in community-dwelling older adults: results from the ESTHER cohort study. Eur $J$ Epidemiol.2014;29:171-9.

14. Bouillon $K$, Kivimäki $M$, Hamer $M$ et al. Diabetes risk factors, diabetes risk algorithms, and the prediction of future frailty: the Whitehall II prospective cohort study. J Am Med Dir Assoc. 2013;14:851. e1-. e6.

15. Crow RS, Lohman MC, Titus AJ et al. Mortality risk along the frailty spectrum: data from the National Health and Nutrition Examination Survey 1999 to 2004. J Am Geriatr Soc. 2018;66:496-502.

16. Fried LP, Tangen CM, Walston $\mathrm{J}$ et al. Frailty in older adults: evidence for a phenotype. $J$ Gerontol A Biol Sci Med Sci. 2001;56:M146-M57.

17. Chhetri JK, Zheng Z, Xu X et al. The prevalence and incidence of frailty in Pre-diabetic and diabetic community-dwelling older population: results from Beijing longitudinal study of aging II (BLSA-II). BMC Geriatr. 2017;17:47.

18. Sinclair AJ, Abdelhafiz A, Dunning $T$ et al. An international position statement on the management of frailty in diabetes mellitus: summary of recommendations 2017. J Frailty Aging. 2018;7:10-20.

19. Hoogendijk EO, Afilalo J, Ensrud $\mathrm{KE}$ et al. Frailty: implications for clinical practice and public health. Lancet. 2019;394(10206):1365-75.

20. Baumgartner RN. Body composition in healthy aging. Ann N Y Acad Sci 2000;904:437-48.

21. Quartuccio M, Buta B, Kalyani RR. Comparative effectiveness for glycemic control in older adults with diabetes. Curr Geriatr Rep. 2017;6:175-86.

22. Steiner G. Treating lipid abnormalities in patients with type 2 diabetes mellitus. Am J Cardiol. 2001;88:37-40.

23. Kocak MZ. Letter to the editor regarding the article 'Frailty and skeletal muscle in older adults with cancer'. J Geriatr Oncol. 2020;11:1041.

24. Peterson MD, McGrath R, Zhang $\mathrm{P}$ et al. Muscle weakness is associated with diabetes in older Mexicans: the Mexican health and aging study. $J$ Am Med Dir Assoc. 2016;17:933-8.

25. Peterson MD, Zhang $\mathrm{P}$, Choksi $\mathrm{P}$ et al. Muscle weakness thresholds for prediction of diabetes in adults. . Sport Med. 2016;46:619-28.

26. McGrath R, Vincent BM, Al Snih $\mathrm{S}$ et al. The association between muscle weakness and incident diabetes in older Mexican Americans. $\mathrm{J} \mathrm{Am} \mathrm{Med}$ Dir Assoc. 2017;18:452. e7-. e12.

27. Kocak MZ. Comment on "Frailty screening by Geriatric-8 and 4-meter gait speed test is feasible and predicts postoperative complications in elderly colorectal cancer patients". J Geriatr Oncol. 2021.

28. Machii N, Kudo A, Saito H, Tanabe $\mathrm{H}$ et al. Walking Speed is the Sole Determinant Criterion of Sarcopenia of Mild Cognitive Impairment in
Japanese Elderly Patients with Type 2 Diabetes Mellitus. J Clin Med. 2020;9:2133. 